\title{
Genotypic Variation in the Postharvest Performance and Ethylene Sensitivity of Cut Rose Flowers
}

\author{
Andrew J. Macnish, Ria T. Leonard, Ana Maria Borda, and \\ Terril A. Nell ${ }^{1}$ \\ Department of Environmental Horticulture, University of Florida, P.O. Box \\ 110670, Gainesville, FL 32611
}

Additional index words. abscission, flower opening, 1-methylcyclopropene, Rosa $\times$ hybrida, senescence, silver thiosulfate

\begin{abstract}
Natural variation in the postharvest quality and longevity of ornamental plants can often be related to differences in their response to ethylene. In the present study, we determined the postharvest performance and ethylene sensitivity of cut flowers from 38 cultivated Hybrid Tea rose genotypes. The vase life of the cultivars varied considerably from 4.5 to 18.8 days at $21^{\circ} \mathrm{C}$. There was also substantial variation in the degree of flower opening among genotypes. Exposure to $1 \mu \mathrm{L} \cdot \mathrm{L}^{-1}$ ethylene for $24 \mathrm{~h}$ at $21^{\circ} \mathrm{C}$ reduced the longevity of 27 cultivars by 0.8 to 8.4 days (18\% to $47 \%$ ) by accelerating petal wilting and abscission. Ethylene treatment also significantly reduced rates of flower opening in 17 sensitive cultivars and in six cultivars that showed no ethylene-related reduction in vase life. Five cultivars showed no reduction in vase life or flower opening in response to ethylene exposure. Pre-treating stems with $0.2 \mathrm{~mm}$ silver thiosulfate liquid or $0.9 \mu \mathrm{L} \cdot \mathrm{L}^{-1}$ 1-methylcyclopropene (1-MCP) gas for $16 \mathrm{~h}$ at $2{ }^{\circ} \mathrm{C}$ reduced the deleterious effects of ethylene. The release of 1-MCP from two sachets containing EthylBloc ${ }^{\mathrm{TM}}$ into individual shipping boxes also protected flowers against ethylene applied immediately after a 6-d commercial shipment. The duration of protection afforded by the 1-MCP sachet treatment was greatest when flowers were maintained at low temperature.
\end{abstract}

The postharvest performance of many ornamental plants varies considerably among cultivars (Halevy and Mayak, 1979). This variation can often be related to differences in the capacity of floral tissues to synthesize and/or perceive the plant hormone ethylene (Muller et al., 1998; Serek and Reid, 2000; $\mathrm{Wu}$ et al., 1991a). Ethylene is the primary promoter of floral organ abscission and senescence in a wide range of flowering plants (van Doorn, 2001; Woltering and van Doorn, 1988). This gaseous molecule binds to transmembrane regions of receptor proteins in plant cells and activates downstream gene transcription and translation (Bleecker and Kende, 2000).

Hybrid Tea roses (Rosa $\times$ hybrida) are among the most economically important and genetically diverse cut flowers (Cairns et al., 2000). Although roses are not typically classified as a highly ethylene sensitive com-

\footnotetext{
Received for publication 15 Jan. 2010. Accepted for publication 12 Mar. 2010.

We gratefully acknowledge the financial support of the American Floral Endowment and the Produce Marketing Association. We thank growers in Colombia and Ecuador for providing flowers and Floralife Inc., AgroFresh Inc., and Chrysal USA Inc. for supplying floral products. We thank Amy Alexander, Dianne Amendola, Yvonne Arwood, and Camila Paula for technical assistance and Dr. Jianjun Chen and Dr. Jeff Million for reviewing the manuscript.

${ }^{1}$ To whom reprint requests should be addressed; e-mail tanell@ufl.edu.
}

modity (Woltering and van Doorn, 1988), their response to ethylene varies. Reid et al. (1989) showed that treatment of 27 rose cultivars with $0.5 \mu \mathrm{L} \cdot \mathrm{L}^{-1}$ ethylene for $2 \mathrm{~d}$ accelerated, inhibited, or had no effect on rates of flower opening. The effects of ethylene on vase life were, however, not reported. Observations by commercial growers suggest that current rose cultivars continue to differ in their sensitivity to ethylene as judged by variable flower opening and vase life (A. Mora and D. Rule, personal communication). Because ethylene can accumulate within enclosed areas used to market cut flowers (Skog et al., 2001) and transport-related stress (e.g., water deficit) can stimulate elevated rates of ethylene synthesis by plant tissues (Muller et al., 2000), quantification of the ethylene sensitivity of different rose cultivars could assist future breeding programs and postharvest handling practices.

Treatment with silver thiosulfate (STS) liquid, an inhibitor of ethylene binding, has been widely used to protect sensitive cut flowers against ethylene (Nowak and Rudnicki, 1990). However, concerns associated with handling and disposing silver solutions are prompting legislators to prohibit STS use (Nell, 1992). 1-Methylcyclopropene (1-MCP) gas is an alternative and nontoxic ethylenebinding inhibitor registered for use on ornamentals (Reid and Staby, 2008; Serek et al., 1994). Commercial preparations such as EthylBloc $^{\mathrm{TM}}$ (Floralife, Inc., Walterboro, SC) release 1-MCP from $\alpha$-cyclodextrin polymers when dissolved in water (Daly and
Kourelis, 2000). However, 1-MCP can be difficult to apply efficiently as a result of its gaseous nature. An alternative delivery system, whereby EthylBloc ${ }^{\mathrm{TM}}$ is enclosed in paper sachets resembling tea bags, may be a more convenient mode of 1-MCP application (Kostansek, 2002). Once dipped in water to initiate 1-MCP release, sachets could easily be used to treat cut flowers within closed shipping boxes (Reid and Celikel, 2008). This new 1-MCP delivery system has not been tested on cut roses.

In the present study, we quantified the postharvest performance and ethylene sensitivity of cut flowers from 38 cultivated rose genotypes. The efficacy of STS pulse and 1-MCP fumigation and sachet treatments to protect responsive genotypes against ethylene during simulated and commercial shipments was tested. We also determined the duration that these treatments could protect flowers at different storage and display temperatures.

\section{Materials and Methods}

\section{Plant material}

Flowers of 38 Hybrid Tea rose cultivars were harvested at commercial maturity (i.e., outer petals starting to reflex) from farms near Bogotá, Colombia, and Quito, Ecuador (Table 1). Flowers were graded for uniform quality, combined into bunches of 25 stems, and recut to $50-\mathrm{cm}$ length in accordance with commercial practice.

\section{General processing}

Unless otherwise stated, bunched flowers were placed after harvest into a commercial hydration solution $\left(2 \mathrm{~mL} \cdot \mathrm{L}^{-1}\right.$ Chrysal Clear Professional 1; Chrysal International B.V., Naarden, The Netherlands) for $16 \mathrm{~h}$ at $2{ }^{\circ} \mathrm{C}$. Bunches were then packed dry into fiberboard flower boxes $(104 \mathrm{~cm}$ long, $25 \mathrm{~cm}$ wide, $17 \mathrm{~cm}$ high) as per commercial practice. A data logger $\left(\mathrm{HOBO}^{\circledR} \mathrm{U} 10-001\right.$; Onset Computer Corp., Bourne, MA) that recorded temperature was placed into a randomly selected box. The boxes were transported by airplane and refrigerated truck through Miami, FL, to the University of Florida in Gainesville, FL, within 5 to $11 \mathrm{~d}$ depending on the experiment. The range in transport time represented prevailing variation in schedules at the wholesale and freight forwarding stages of shipment (Fig. 1) and provided a true commercial test for flower treatments. At the laboratory, all except the uppermost three leaves were detached by hand and the cut ends of stems were trimmed by $5 \mathrm{~cm}$ perpendicular to the stem. Stems were placed in a commercial processing solution $\left(10 \mathrm{~mL} \cdot \mathrm{L}^{-1}\right.$ Chrysal Clear Professional 2; Chrysal International B.V.) to simulate retail handling and then transferred to a commercial vase solution (Chrysal Clear Professional 3; Chrysal International B.V.) for evaluation.

Expt. 1: Ethylene sensitivity. Flower stems were processed at the laboratory as described previously and placed into $3-\mathrm{L}$ 
Table 1. Flower vase life and maximum opening score for 38 rose (Rosa xhybrida) cultivars at $21{ }^{\circ} \mathrm{C}$ after exposure to 0 or $1 \mu \mathrm{L} \cdot \mathrm{L}^{-1}$ ethylene for $24 \mathrm{~h}$ at $21{ }^{\circ} \mathrm{C}$.

\begin{tabular}{|c|c|c|c|c|c|}
\hline \multirow[b]{2}{*}{ Cultivar } & \multirow[b]{2}{*}{ Farm location } & \multicolumn{2}{|c|}{ Vase life (d) } & \multicolumn{2}{|c|}{ Opening score ${ }^{\mathrm{z}}$} \\
\hline & & No ethylene & Plus ethylene & No ethylene & Plus ethylene \\
\hline Amberw & Ecuador & $11.8 \pm 0.4$ & $8.7 \pm 0.5^{*}$ & $5.0 \pm 0.0$ & $4.8 \pm 0.2 \mathrm{NS}$ \\
\hline Amorous $^{\mathrm{w}}$ & Ecuador & $7.0 \pm 0.4$ & $5.6 \pm 0.4 \mathrm{NS}$ & $3.4 \pm 0.2$ & $2.4 \pm 0.2^{*}$ \\
\hline Black Magic ${ }^{y}$ & Colombia & $5.7 \pm 0.5$ & $4.6 \pm 0.3 \mathrm{NS}$ & $2.7 \pm 0.4$ & $2.3 \pm 0.3 \mathrm{NS}$ \\
\hline Brooke $^{\mathrm{w}}$ & Ecuador & $7.2 \pm 0.3$ & $5.9 \pm 0.2^{*}$ & $2.6 \pm 0.1$ & $2.1 \pm 0.1 *$ \\
\hline Carrousel $^{\mathrm{w}}$ & Colombia & $15.6 \pm 0.2$ & $13.6 \pm 0.6^{*}$ & $2.0 \pm 0.1$ & $1.9 \pm 0.1 \mathrm{NS}$ \\
\hline Circus $^{\mathrm{x}}$ & Ecuador & $7.9 \pm 0.4$ & $6.4 \pm 0.7^{*}$ & $4.6 \pm 0.2$ & $4.3 \pm 0.3 \mathrm{NS}$ \\
\hline Clear Ocean ${ }^{\mathrm{w}}$ & Colombia & $12.5 \pm 0.7$ & $10.3 \pm 0.6^{*}$ & $3.3 \pm 0.2$ & $2.6 \pm 0.2 \mathrm{NS}$ \\
\hline Cool Water ${ }^{\mathrm{w}}$ & Colombia & $6.9 \pm 0.7$ & $5.2 \pm 0.7 \mathrm{NS}$ & $2.9 \pm 0.1$ & $2.9 \pm 0.1 \mathrm{NS}$ \\
\hline Engagement ${ }^{\mathrm{w}}$ & Colombia & $9.0 \pm 0.1$ & $7.4 \pm 0.3^{*}$ & $2.3 \pm 0.1$ & $1.7 \pm 0.1 *$ \\
\hline Erin $^{w}$ & Ecuador & $17.7 \pm 0.3$ & $9.3 \pm 0.3^{*}$ & $5.0 \pm 0.0$ & $5.0 \pm 0.0 \mathrm{NS}$ \\
\hline Esperance $^{\mathrm{w}}$ & Colombia & $18.8 \pm 0.6$ & $17.2 \pm 0.8 \mathrm{NS}$ & $4.2 \pm 0.1$ & $4.2 \pm 0.1 \mathrm{NS}$ \\
\hline Forever Young ${ }^{\mathrm{w}}$ & Ecuador & $18.3 \pm 0.4$ & $17.0 \pm 0.5 \mathrm{NS}$ & $3.4 \pm 0.1$ & $3.0 \pm 0.1^{*}$ \\
\hline Leonidas $^{\mathrm{x}}$ & Ecuador & $5.9 \pm 0.5$ & $4.1 \pm 0.1^{*}$ & $3.1 \pm 0.2$ & $1.5 \pm 0.2 *$ \\
\hline Lina $^{w}$ & Colombia & $4.5 \pm 0.3$ & $3.6 \pm 0.3^{*}$ & $1.6 \pm 0.1$ & $1.5 \pm 0.0 \mathrm{NS}$ \\
\hline Lindsey ${ }^{\mathrm{w}}$ & Ecuador & $4.5 \pm 0.1$ & $3.7 \pm 0.1^{*}$ & $5.0 \pm 0.0$ & $4.8 \pm 0.1 \mathrm{NS}$ \\
\hline Lovely Dream ${ }^{x}$ & Ecuador & $4.6 \pm 0.3$ & $4.4 \pm 0.3 \mathrm{NS}$ & $4.1 \pm 0.2$ & $3.4 \pm 0.1^{*}$ \\
\hline N-Joy ${ }^{\mathrm{x}}$ & Ecuador & $7.2 \pm 0.5$ & $4.1 \pm 0.2 *$ & $3.8 \pm 0.1$ & $2.8 \pm 0.1 *$ \\
\hline Osiana $^{y}$ & Colombia & $8.0 \pm 1.1$ & $1.8 \pm 1.0^{*}$ & $4.3 \pm 0.4$ & $\mathrm{v}$ \\
\hline Peach Sherbet ${ }^{\mathrm{w}}$ & Ecuador & $9.6 \pm 1.1$ & $5.7 \pm 0.3^{*}$ & $4.6 \pm 0.1$ & $3.6 \pm 0.2^{*}$ \\
\hline Pekcoubo $^{w}$ & Colombia & $9.9 \pm 0.3$ & $8.0 \pm 0.4^{*}$ & $3.1 \pm 0.2$ & $2.0 \pm 0.2 *$ \\
\hline Pink Engagement ${ }^{\mathrm{w}}$ & Colombia & $8.8 \pm 0.3$ & $5.9 \pm 0.3^{*}$ & $3.8 \pm 0.2$ & $2.7 \pm 0.1^{*}$ \\
\hline Ravel $^{\mathrm{x}}$ & Ecuador & $15.2 \pm 0.5$ & $14.9 \pm 0.3 \mathrm{NS}$ & $2.5 \pm 0.2$ & $2.8 \pm 0.3 \mathrm{NS}$ \\
\hline Red Sensation ${ }^{\mathrm{x}}$ & Ecuador & $10.9 \pm 1.3$ & $7.8 \pm 0.7^{*}$ & $3.4 \pm 0.1$ & $1.9 \pm 0.3^{*}$ \\
\hline Rubor $^{y}$ & Colombia & $5.0 \pm 0.3$ & $2.4 \pm 0.2^{*}$ & $2.1 \pm 0.3$ & $1.0 \pm 0.0^{*}$ \\
\hline Shocking Versilia ${ }^{\mathrm{w}}$ & Colombia & $13.0 \pm 0.6$ & $10.3 \pm 0.5^{*}$ & $2.4 \pm 0.2$ & $1.7 \pm 0.1 *$ \\
\hline
\end{tabular}

${ }^{\mathrm{z}}$ Flower opening score: $1=$ outer petals tightly wrapped around bud; $5=$ outer petals reflexed at $90^{\circ}$ to stem.

$\mathrm{y}, \mathrm{x},{ }^{w}$ Data are representative of 12,16 , and 24 replicate stems, respectively.

${ }^{v}$ No flower opening score could be recorded as a result of petal abscission.

Ns, *Nonsignificant or significant differences at $P=0.05$, respectively, between ethylene treatments for vase life or opening data.

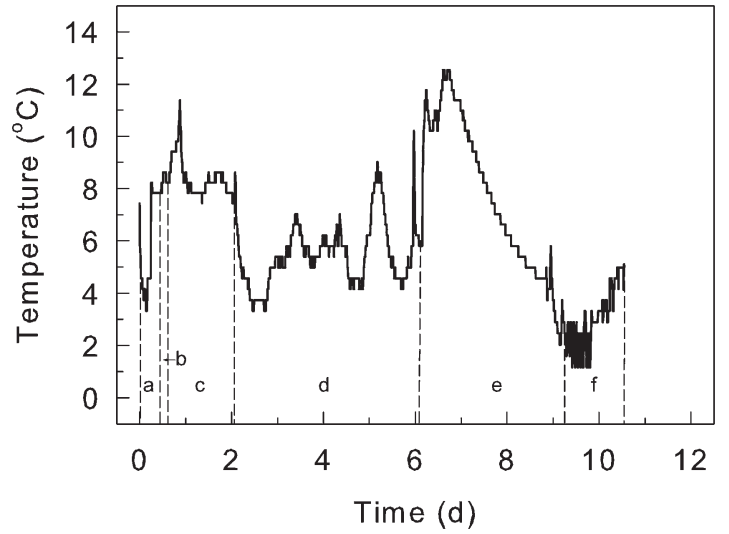

Fig. 1. Temperatures recorded inside a box containing cut rose flowers during shipment from Bogotá, Colombia, to Gainesville, FL. Shipment handling stages: a = truck transport from farm to Bogotá airport; $\mathrm{b}=$ on board aircraft (Bogotá to Miami); $\mathrm{c}=$ airline cargo section (Miami); $\mathrm{d}=$ Miami wholesaler; $\mathrm{e}=$ Miami freight forwarding company; $\mathrm{f}=$ truck transport from Miami to Gainesville.

glass vases containing the commercial processing solution. Six stems were included in each vase. They were then enclosed into 99-L glass chambers and exposed to 0 (control) or $1 \mu \mathrm{L} \cdot \mathrm{L}^{-1}$ ethylene in a flowing air stream $\left(0.6 \mathrm{~L} \cdot \mathrm{min}^{-1}\right)$ for $24 \mathrm{~h}$ at $21{ }^{\circ} \mathrm{C}$ under $10 \mu \mathrm{mol} \cdot \mathrm{m}^{-2} \cdot \mathrm{s}^{-1}$ of light. Ethylene concentrations inside chambers were quantified with a gas chromatograph (GC) (5890 Series II; Hewlett Packard, Avondale, PA) fitted with a flame ionization detector. The GC was calibrated with a known ethylene standard (Air Liquid America Specialty Gases LLC, Plumsteadville, PA). After treatment, stems were transferred to matching vases containing the commercial vase solution. They were maintained for evaluation at $21{ }^{\circ} \mathrm{C}$, $40 \%$ to $60 \%$ relative humidity, and under $10 \mu \mathrm{mol} \cdot \mathrm{m}^{-2} \cdot \mathrm{s}^{-1}$ of light $\left(12 \mathrm{~h} \cdot \mathrm{d}^{-1}\right)$ provided by cool white fluorescent bulbs. The experiment was repeated twice for most cultivars using 12 to 24 replicate stems per treatment. Where variation in ethylene sensitivity was observed between duplicated experiments, data showing the most significant response was presented.

Expt. 2: Silver thiosulfate pulse and 1methylcyclopropene fumigation and sachet treatment. The efficacy of STS pulse and 1$\mathrm{MCP}$ fumigation and sachet treatments to protect three ethylene-responsive rose cultivars (Charlotte, Clear Ocean, Osiana) against ethylene was tested. Twenty freshly harvested flower bunches of each cultivar were randomly allocated to buckets containing the commercial hydration solution (control) or $0.2 \mathrm{~mm}$ STS (provided as $1 \mathrm{~mL} \cdot \mathrm{L}^{-1} \mathrm{AVB}$; 
Chrysal International B.V.) and enclosed into an airtight tent made from polyethylene film. An additional 10 bunches of each cultivar in the hydration solution were fumigated with $0.9 \mu \mathrm{L} \cdot \mathrm{L}^{-1} 1-\mathrm{MCP}$ released from EthylBloc ${ }^{\mathrm{TM}}$ (a.i. $0.014 \%$ 1-MCP; Floralife, Inc.) within a matching polyethylene tent. The 1-MCP treatment concentration was theoretical and based on calculations provided by the manufacturer. Bunches were exposed to their respective treatments for $16 \mathrm{~h}$ at $2{ }^{\circ} \mathrm{C}$. Two bunches of the three cultivars were then randomly sampled and packed into each flower box as described previously. Half of the boxes containing control bunches were exposed to the 1-MCP sachet treatment. Briefly, two sachets containing $2.5 \mathrm{~g}$ Ethyl$\mathrm{Bloc}^{\mathrm{TM}}$ (Floralife, Inc.) powder were dipped in water for $1 \mathrm{~s}$ to initiate 1-MCP release and immediately placed in among the flower bunches at $20 \mathrm{~cm}$ from either end of each box as prescribed by the manufacturer. Sachets remained inside boxes for the duration of shipment and/or post-shipment storage. Three replicate boxes per treatment were used. All boxes were transported together from the farm to the laboratory in $11 \mathrm{~d}$. Six stems from each bunch were then sampled, processed, randomly assigned to vases containing the commercial processing solution, and exposed to 0 or $1 \mu \mathrm{L} \cdot \mathrm{L}^{-1}$ ethylene as described previously. Eighteen replicate stems from each treatment combination were then maintained for evaluation in the commercial vase solution (six stems per vase) as for Expt. 1.

Expt. 3: Duration of 1-methylcyclopropene fumigation treatment effects. Given that 1-MCP fumigation did not render 'Osiana' flowers insensitive to ethylene $11 \mathrm{~d}$ after treatment (Expt. 2), we conducted a study to determine the maximum duration that this treatment could protect flowers. Twelve 'Osiana' flower bunches were treated in the commercial hydration solution and transported from the farm to the laboratory in $5 \mathrm{~d}$ as described previously. Stem bases were trimmed by $5 \mathrm{~cm}$ and placed into the commercial hydration solution to simulate farm handling. Six bunches were fumigated with $0.9 \mu \mathrm{L} \cdot \mathrm{L}^{-1} 1-\mathrm{MCP}$ for $16 \mathrm{~h}$ at $2{ }^{\circ} \mathrm{C}$. An additional six control bunches were not fumigated and were held in another polyethylene tent in air. The six bunches were then repacked into a single replicate box per treatment as described previously. Bunches in boxes were held at $6^{\circ} \mathrm{C}$ for $11 \mathrm{~d}$ to simulate the average temperature and duration of shipment in Expt. 2. On 0, 3, 6, 9, and $11 \mathrm{~d}$ after 1-MCP treatment, four flower stems were sampled from each of the six bunches per treatment. Stems were processed, randomly allocated to vases containing the commercial processing solution for $1 \mathrm{~h}$ to equilibrate to $21^{\circ} \mathrm{C}$, and then exposed to 0 or $1 \mu \mathrm{L} \cdot \mathrm{L}^{-1}$ ethylene as previously described. The 12 replicate stems from each treatment combination were transferred to vases containing the commercial vase solution (six stems per vase) and maintained for evaluation as for Expt. 1.
Expt. 4: High temperature and the duration of silver thiosulfate and 1-methylcyclopropene sachet treatment effects. The duration that STS pulse and 1-MCP sachet treatments could protect flowers against ethylene during post-shipment vase life at $21{ }^{\circ} \mathrm{C}$ was determined. Twenty freshly harvested flower bunches of 'Clear Ocean' and 'Osiana' were placed into the commercial hydration solution (control) or $0.2 \mathrm{~mm} \mathrm{STS} \mathrm{for} 16 \mathrm{~h}$ at $2{ }^{\circ} \mathrm{C}$. Three bunches of both cultivars from each treatment were randomly sampled and packed into separate flower boxes as described previously. Two EthylBloc ${ }^{\text {TM }}$ (Floralife, Inc.) sachets were placed into half of the boxes containing control bunches as described previously. Three replicate boxes per treatment were used. Boxes were then transported from the farm to the laboratory in $6 \mathrm{~d}$. Stems were processed, placed into vases containing the commercial vase solution (12 stems per vase), and maintained for evaluation as described in Expt. 1. On days $0,2,4,6,8$, and 10 of vase life $(6,8,10,12$, 14 , and $16 \mathrm{~d}$ after anti-ethylene treatments), 24 stems were sampled from each treatment and exposed to either 0 or $1 \mu \mathrm{L} \cdot \mathrm{L}^{-1}$ ethylene as outlined previously. Stems were then returned to vase solution for evaluation.

Expt. 5: Low temperature and the duration of 1-methylcyclopropene sachet treatment effects. The duration that 1-MCP sachet treatment would protect flowers against ethylene during post-shipment storage at $3{ }^{\circ} \mathrm{C}$ was also determined. Twenty 'Osiana' and 'Freedom' flower bunches were treated in the commercial hydration solution for $16 \mathrm{~h}$ at $2{ }^{\circ} \mathrm{C}$. Six bunches of either cultivar were each packed into two flower boxes as described previously. Two EthylBloc ${ }^{\mathrm{TM}}$ (Floralife, Inc.) sachets were placed into one box for each cultivar as previously described. The remaining control boxes did not contain sachets. Boxes were then transported from the farm to the laboratory in $6 \mathrm{~d}$ and held on arrival at $3{ }^{\circ} \mathrm{C}$ to simulate dry storage. Thirty-six stems were randomly sampled from each box on days $0,2,4$, and 6 of storage $(6,8,10$, and $12 \mathrm{~d}$ after 1-MCP treatment). These stems were processed, placed into vases containing the commercial processing solution, and exposed to 0 or $1 \mu \mathrm{L} \cdot \mathrm{L}^{-1}$ ethylene as described previously. The 18 replicate flowers from each treatment combination were then maintained in the commercial vase solution (six stems per vase) for evaluation as for Expt. 1.

\section{Assessments}

Vase life was judged as the time from placement of stems in vases for evaluation to the loss of visual appeal (i.e., moderate petal bluing, disease, drop, wilting, and/or drooping of flower heads). Flower opening was determined every second day of vase life using the following rating score: $1=$ outer petals tightly wrapped around the bud; $2=$ outer petals starting to reflex from the bud; $3=$ outer petals reflexed $\approx 135^{\circ}$ to the stem; $4=$ outer petals reflexed at $\approx 115^{\circ}$ to the stem; and $5=$ outer petals reflexed at $90^{\circ}$ to the stem (modified from Kuiper et al., 1996).

\section{Experiment design and data analysis}

Depending on the experiment, 12 to 24 replicate stems were used for each treatment. Stems in vases were arranged in a completely randomized block design. Data were subjected to analysis of variance (ANOVA) using the generalized linear model procedure of SAS (Version 9.1; SAS Institute Inc., Cary, NC). When the ethylene response of flowers was examined over time (Expts. 3, 4, and 5), data were analyzed using split plot for time in the ANOVA. When significant differences $(P \leq 0.05)$ occurred among the treatments, the least significant difference test at $P=0.05$ was used to separate the means.

\section{Results}

Expt. 1: Ethylene sensitivity of rose flowers. The vase life of the 38 tested rose flower cultivars varied considerably from $4.5 \mathrm{~d}$ ('Lina' and 'Lindsey') to $18.8 \mathrm{~d}$ ('Esperance' and 'Verdi') (Table 1). Similarly, the maximum level of flower opening during vase life ranged from a score of 1.6 (outer petals only partially reflexed) for 'Lina' to 5.0 (outer petals fully reflexed) for 'Amber', 'Erin', and 'Lindsey' (Table 1). Relative to control flowers $\left(0 \mu \mathrm{L} \cdot \mathrm{L}^{-1}\right.$ ethylene $)$, exposure to $1 \mu \mathrm{L} \cdot \mathrm{L}^{-1}$ ethylene for $24 \mathrm{~h}$ at $21^{\circ} \mathrm{C}$ reduced the longevity of 27 cultivars by 0.8 to $8.4 \mathrm{~d}$ ( $18 \%$ to $47 \%$ ) (Table 1). Although ethylene typically accelerated petal wilting (Fig. 1), it also stimulated extensive petal and leaf abscission from 'Osiana' and 'Freedom' stems, respectively (data not shown). Ethylene treatment also reduced the degree of flower opening in 17 of the 27 sensitive cultivars and in six cultivars (Amorous, Forever Young, Gold Strike, Lovely Dream, Sweet Moment, Yabadabadoo) that showed no ethylene-related decrease in vase life (Table 1). In 11 cultivars, the reduction in flower opening was substantial, being at least a score of 1.0 lower than control stems, and was often accompanied by rapid and severe petal wilting (Fig. 2). The cultivars Black Magic, Cherry Love, Cool Water, Esperance, and Ravel showed no reduction in vase life or flower opening in response to ethylene exposure. Typically, the response of cultivars to ethylene was highly reproducible.

Expt. 2: Silver thiosulfate and 1-methylcyclopropene fumigation and sachet treatment of rose flowers. Temperatures inside a randomly selected box varied from 1.2 to $10.2{ }^{\circ} \mathrm{C}$ during the $11-\mathrm{d}$ commercial shipment from Bogotá, Colombia, to Gainesville, FL (Fig. 1). Pulsing 'Charlotte', 'Clear Ocean', and 'Osiana' stems with $0.2 \mathrm{~mm}$ STS for $16 \mathrm{~h}$ at $2{ }^{\circ} \mathrm{C}$ before transport protected flowers against post-shipment ethylene treatment (Fig. 3). Fumigating 'Charlotte' and 'Osiana' stems with $0.9 \mu \mathrm{L} \cdot \mathrm{L}^{-1}$ 1-MCP gas for $16 \mathrm{~h}$ immediately before transport did not completely render flowers insensitive to the ethylene treatment as evidenced by a reduction in vase life relative to STS-treated stems. Inclusion of two Ethyl$\mathrm{Bloc}^{\mathrm{TM}}$ sachets that released 1-MCP into 


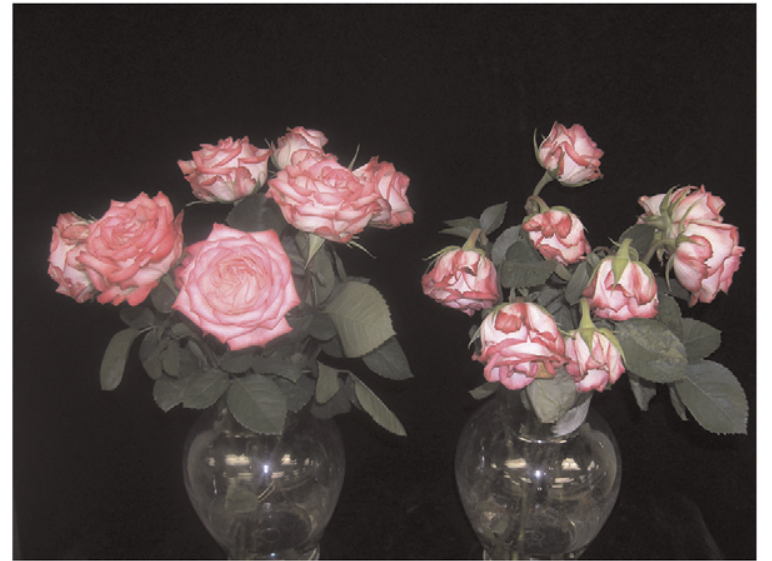

Fig. 2. Photograph of rose (Rosa $\times$ hybrida) 'N-Joy' flowers on day 4 of vase life at $21{ }^{\circ} \mathrm{C}$ after treatment with 0 (left) or 1 (right) $\mu \mathrm{L} \cdot \mathrm{L}^{-1}$ ethylene on day 0 for $24 \mathrm{~h}$ at $21^{\circ} \mathrm{C}$. Exposure to ethylene reduced the degree of flower opening and accelerated petal wilting.

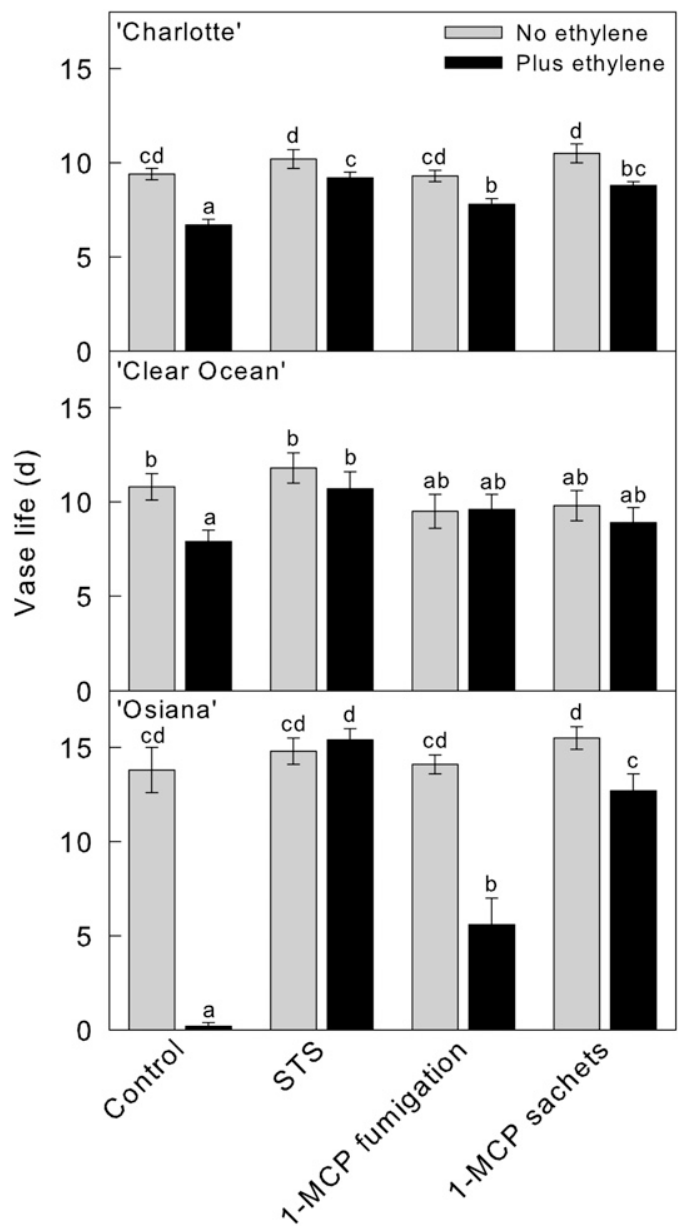

Fig. 3. Vase life of rose (Rosa $\times$ hybrida) 'Charlotte', 'Clear Ocean', and 'Osiana' flowers at $21{ }^{\circ} \mathrm{C}$ after pre-treatment with water (control), $0.2 \mathrm{mM}$ silver thiosulfate (STS), or $0.9 \mu \mathrm{L} \cdot \mathrm{L}^{-1} 1$-methylcyclopropene (1-MCP) for $16 \mathrm{~h}$ at $2{ }^{\circ} \mathrm{C}$. Additional flowers pre-treated with water were exposed to two EthylBloc ${ }^{\mathrm{TM}}$ sachets that released 1-MCP during shipment. All flowers were transported in boxes from the farm to the laboratory in $11 \mathrm{~d}$ whereupon they were exposed to 0 or $1 \mu \mathrm{L} \cdot \mathrm{L}^{-1}$ ethylene for $24 \mathrm{~h}$ at $21^{\circ} \mathrm{C}$. Data (mean $\pm \mathrm{SE}, \mathrm{n}=18$ ) for each cultivar followed by different letters are significantly different at $P=0.05$.

flower boxes during shipment was, however, relatively more effective for protecting 'Osiana' flowers and equally as effective as STS treatment for 'Charlotte' flowers. The vase life of 'Clear Ocean' flowers fumigated with 1-MCP or exposed to sachets was, however, not different from the control stems. For all the tested cultivars, treatment with STS and
1-MCP did not extend the vase life of control flowers not exposed to exogenous ethylene (Fig. 3). Although ethylene did not inhibit the opening of 'Clear Ocean' flowers, treatment with 1-MCP and STS reduced the deleterious effects of ethylene on flower opening of 'Charlotte' and 'Osiana' (data not shown).

Expt. 3: Duration of 1-methylcyclopropene fumigation treatment effects. Fumigating 'Osiana' flowers with 1-MCP prevented ethylene-induced petal abscission and the associated loss in vase life for $3 \mathrm{~d}$ of simulated dry transport at $6{ }^{\circ} \mathrm{C}$ (Table 2). The 1-MCP pre-treatment continued to partially protect flowers against exogenous ethylene on day 6 of dry transport. Thereafter, there was no residual activity of the 1-MCP treatment. Where 1-MCP pre-treatment was effective in preventing petal abscission, flowers opened fully during vase life at rates consistent with control stems not exposed to ethylene (data not shown). Transporting 'Osiana' flowers for $9 \mathrm{~d}$ or longer at $6{ }^{\circ} \mathrm{C}$ was associated with a dramatic reduction in subsequent vase life (Table 2). Fumigation with 1-MCP significantly reduced the loss in vase life associated with extended periods ( $9 \mathrm{~d}$ or longer) of dry transport.

Expt. 4: High temperature and the duration of silver thiosulfate and 1-methylcyclopropene sachet treatment effects. Treating 'Osiana' and 'Clear Ocean' bunches with STS or 1-MCP by EthylBloc ${ }^{\mathrm{TM}}$ sachets in shipping boxes prevented the reduction in vase life (Fig. 4) and flower opening (data not shown) associated with ethylene exposure immediately after a 6-d shipment at $7.3 \pm 0.2{ }^{\circ} \mathrm{C}$. Thereafter, STS pulsing only afforded 'Osiana' and 'Clear Ocean' flowers with protection against ethylene for 2 and $4 \mathrm{~d}$ of vase life at $21{ }^{\circ} \mathrm{C}$ ( 8 and $10 \mathrm{~d}$ after sachet pretreatment), respectively, whereas the $1-\mathrm{MCP}$ sachets no longer offered protection. Treatment with STS and 1-MCP sachets did not improve the opening and longevity of flowers not exposed to exogenous ethylene (data not shown).

Expt. 5: Low temperature and the duration of 1-methylcyclopropene sachet treatment effects. The EthylBloc ${ }^{\mathrm{TM}}$ sachets prevented the significant reduction in 'Freedom' flower longevity associated with ethylene treatment immediately after the 6-d shipment at $3.8 \pm 0.1{ }^{\circ} \mathrm{C}$ (Fig. 5). The sachet treatment continued to protect 'Freedom' flowers against serial ethylene exposures for a further $6 \mathrm{~d}$ of dry storage at $3{ }^{\circ} \mathrm{C}$. In contrast, 1-MCP sachets only afforded 'Osiana' flowers with partial protection against post-shipment ethylene exposure as evidenced by petal abscission and the associated reduction in vase life relative to control stems not exposed to ethylene (Fig. 5). 1-MCP sachet treatment did not extend the longevity of 'Freedom' and 'Osiana' flowers that were not exposed to ethylene after transport. Exposure to 1-MCP sachets also prevented the reduction in 'Freedom' flower opening resulting from treatment with ethylene immediately after shipment (Fig. 6). A similar level of protection was maintained for 
Table 2. Vase life of rose (Rosa $\times$ hybrida) 'Osiana' flowers pre-treated with 0 (control) or $0.9 \mu \mathrm{L} \cdot \mathrm{L}^{-1} 1$-MCP for $16 \mathrm{~h}$ at $2{ }^{\circ} \mathrm{C}$ on day 0 before simulated dry transport at $6{ }^{\circ} \mathrm{C}$ for $11 \mathrm{~d} .^{\mathrm{z}}$

\begin{tabular}{|c|c|c|c|c|c|c|}
\hline Pre-treatment & Ethylene treatment & \multicolumn{5}{|c|}{ Vase life (d) } \\
\hline Control & No ethylene & $9.1 \pm 0.9 \mathrm{a}^{\mathrm{y}}$ & $10.8 \pm 1.3 \mathrm{a}$ & $13.0 \pm 1.5 \mathrm{a}$ & $5.8 \pm 1.2 \mathrm{~b}$ & $4.3 \pm 0.7 \mathrm{~b}$ \\
\hline 1-MCP fumigation & $\begin{array}{l}\text { No ethylene } \\
\text { Plus ethylene }\end{array}$ & $\begin{array}{l}7.1 \pm 0.2 \mathrm{~b} \\
8.2 \pm 0.1 \mathrm{a}\end{array}$ & $\begin{array}{r}12.5 \pm 1.6 \mathrm{a} \\
9.9 \pm 1.4 \mathrm{a}\end{array}$ & $\begin{aligned} 10.5 & \pm 1.2 \mathrm{a} \\
5.0 & \pm 1.0 \mathrm{~b}\end{aligned}$ & $\begin{array}{l}8.8 \pm 1.1 \mathrm{a} \\
0.0 \pm 0.0 \mathrm{c}\end{array}$ & $\begin{array}{l}9.3 \pm 1.5 \mathrm{a} \\
0.0 \pm 0.0 \mathrm{c}\end{array}$ \\
\hline
\end{tabular}

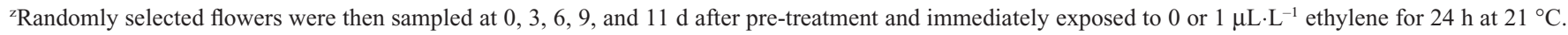
${ }^{y}$ Data (mean $\pm \mathrm{SE}, \mathrm{n}=12$ ) for each ethylene treatment time followed by different letters are significantly different at $P=0.05$.

$1-\mathrm{MCP}=1$-methylcyclopropene.

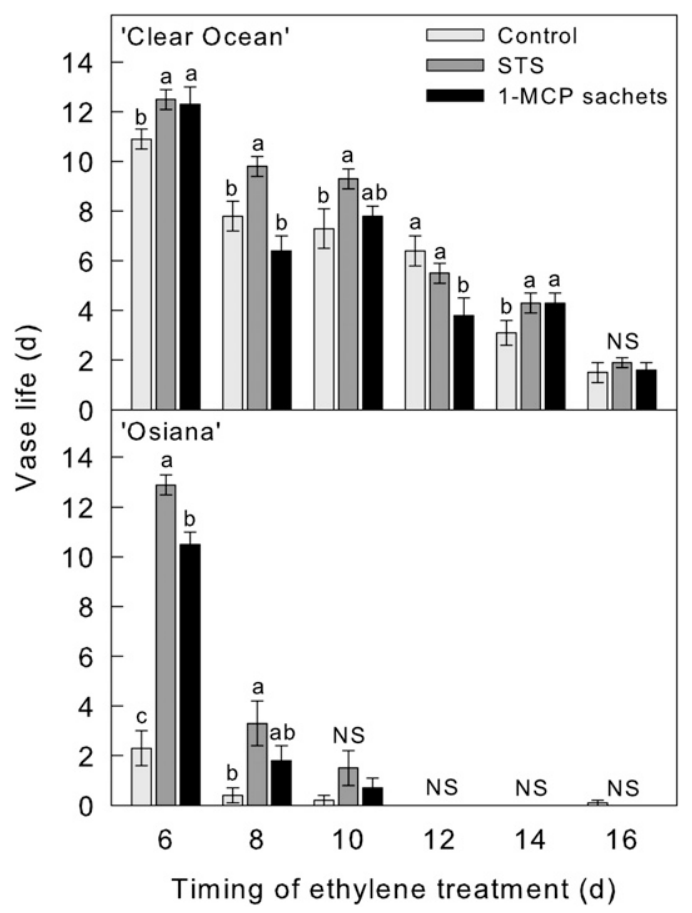

Fig. 4. Vase life at $21^{\circ} \mathrm{C}$ of rose (Rosa $\times$ hybrida) 'Clear Ocean' and 'Osiana' flowers after exposure to $1 \mu \mathrm{L} \cdot \mathrm{L}^{-1}$ ethylene for $24 \mathrm{~h}$ at $21^{\circ} \mathrm{C}$. Flowers were pre-treated on day 0 with water (control) or $0.2 \mathrm{mM}$ silver thiosulfate (STS) for $16 \mathrm{~h}$ at $2{ }^{\circ} \mathrm{C}$ and transported in boxes from the farm to the laboratory in $6 \mathrm{~d}$. Additional flowers pre-treated with water were transported in boxes containing two EthylBloc ${ }^{\mathrm{TM}}$ sachets that released 1-methylcyclopropene (1-MCP). Randomly selected flowers maintained at $21^{\circ} \mathrm{C}$ in vase solution were then exposed to ethylene on $6,8,10,12$, 14, or $16 \mathrm{~d}$ after pre-treatment. Data (mean $\pm \mathrm{SE}, \mathrm{n}=12$ ) for each cultivar and ethylene treatment time followed by different letters are significantly different at $P=0.05$. ns represents nonsignificant.

'Freedom' flowers exposed to ethylene 8, 10, and $12 \mathrm{~d}$ after exposure to the sachet (data not shown). When 1-MCP treatment prevented petal abscission from 'Osiana' stems, the flowers opened fully (data not shown).

\section{Discussion}

Our finding that the postharvest performance of cut rose flowers varied substantially among 38 cultivars (Table 1) reflects the tremendous genetic diversity in Rosa $\times$ hybrida genotypes. Modern roses are the products of intensive breeding activity with European and Chinese rose species and complex hybridizations (Cairns et al., 2000). Considerable natural variation in postharvest longevity and quality has also been reported to exist for different cultivars of carnation, kalanchoe, and miniature rose (Muller et al., 1998; Serek and Reid, 2000; Wu et al., 1991a). This variation should provide interesting opportunities for breeders to select for genotypes with uniformly superior postharvest characteristics.

Exposure to ethylene accelerates floral organ abscission and senescence in a range of cut flowers, including rose (van Doorn, 2001; Woltering and van Doorn, 1988). In the current study, treatment with ethylene reduced flower opening and/or vase life in $87 \%$ of cultivars to varying degrees (Table $1)$. This observed variation in ethylene sensitivity is consistent with similar reports for carnation (Onozaki et al., 2001; Wu et al., 1991b), Chamelaucium (Macnish et al., 2004a), kalanchoe (Serek and Reid, 2000), and cut and potted miniature rose (Ahmadi et al., 2009; Muller et al., 1998; Reid et al., 1989). Variation in ethylene sensitivity may relate to differences in the concentration and affinity of the ethylene receptors and/or the activity of downstream components in the signal transduction pathway (Bleecker and Kende, 2000). There was no relationship between differences in ethylene sensitivity and the natural variation in the postharvest performance of roses (Table 1). Nevertheless, our observation that five cultivars were insensitive to a $24-\mathrm{h}$ exposure to $1 \mu \mathrm{L} \cdot \mathrm{L}^{-1}$ ethylene at $21{ }^{\circ} \mathrm{C}$ indicates that ethylene insensitivity occurs in Hybrid Tea roses and this represents an opportunity to exploit this trait in future breeding programs.

We found it interesting that exposure to ethylene always reduced rates of flower opening in responsive cultivars (Table 1). In contrast, ethylene has been shown to accelerate flower opening in some rose genotypes (Reid et al., 1989; Tan et al., 2006). In the current study, the ethylene-related reduction in flower opening was often accompanied by rapid petal wilting (Fig. 2). Xue et al. (2009) recently reported that exposure to ethylene inhibited petal expansion in 'Samantha' rose in association with decreased expression of $R h$-TIP1;1, a gene encoding an aquaporin that serves as a transmembrane channel for water transport in rose petals. Ethylene has also been reported to stimulate the formation of tyloses, outgrowths of parenchyma into xylem lumen, in pruned grape shoots (Sun et al., 2007). This type of vascular occlusion can greatly impede water uptake in cut flowers (van Doorn et al., 1991). Further research is needed to determine the role of ethylene in inhibiting flower opening in different cut rose genotypes.

Although most genotypes were sensitive to ethylene, only five ('Leonidas', 'N-Joy', 'Peach Sherbet', 'Pink Engagement', 'Rubor') cultivars showed a dramatic reduction in both flower longevity ( $30 \%$ or greater) and opening (1.0 score or greater) (Table 1$)$. Pre-treatment with the ethylene binding inhibitors, STS and 1-MCP, successfully reduced these deleterious effects of ethylene (Fig. 3) (Reid et al., 1989; Serek et al., 1995). However, STS pulsing provided longer-term protection against ethylene than 1-MCP fumigation (Fig. 4). Unlike the gaseous 1-MCP, residual unbound silver ions are presumed to remain in plant tissues and may bind to new ethylene receptors that form after STS treatment (Cameron and Reid, 2001; Newman et al., 1998). Our finding that STS treatment protected 'Osiana' and 'Clear Ocean' rose flowers against ethylene for 8 and $10 \mathrm{~d}$, respectively, after treatment conflicts with reports 


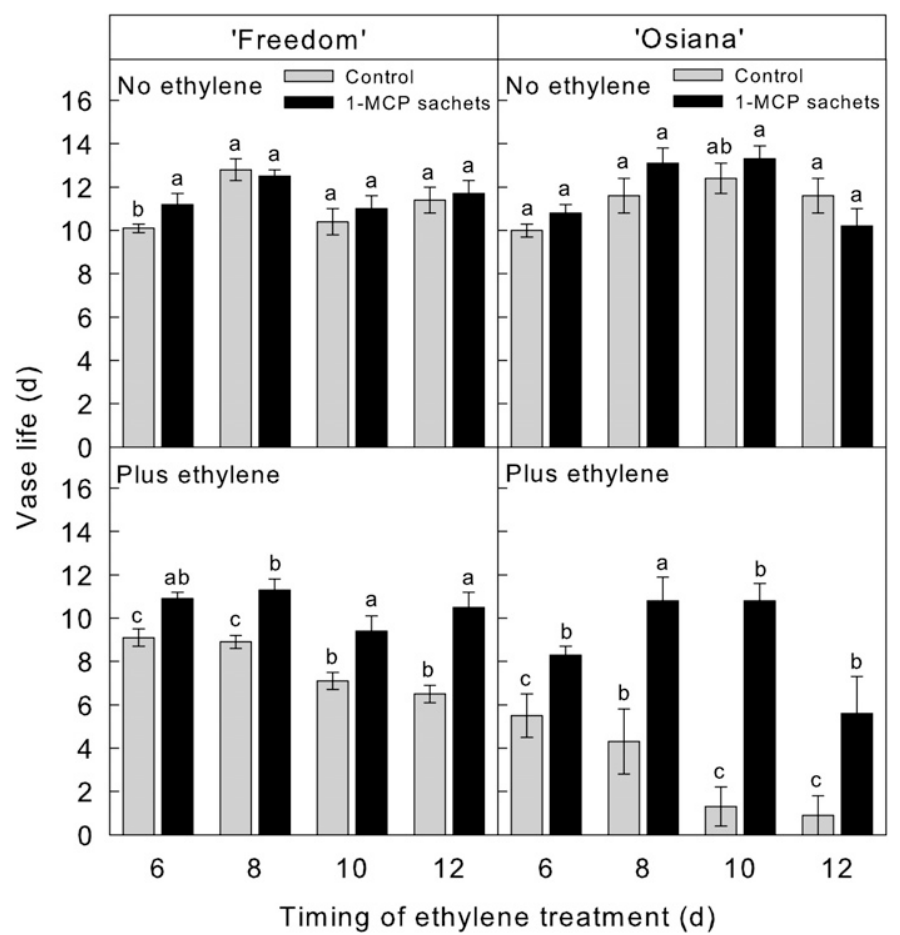

Fig. 5. Vase life at $21^{\circ} \mathrm{C}$ of rose (Rosa $\times$ hybrida) 'Freedom' and 'Osiana' flowers after exposure to $1 \mu \mathrm{L} \cdot \mathrm{L}^{-1}$ ethylene for $24 \mathrm{~h}$ at $21^{\circ} \mathrm{C}$. Flowers were hydrated in the commercial hydration solution for $16 \mathrm{~h}$ at $2{ }^{\circ} \mathrm{C}$. They were transported from the farm to the laboratory in $6 \mathrm{~d}$ in boxes containing zero (control) or two EthylBloc ${ }^{\mathrm{TM}}$ sachets that released 1-methylcyclopropene (1-MCP). Randomly selected flowers maintained in boxes at $3{ }^{\circ} \mathrm{C}$ were then exposed to ethylene on days $6,8,10$, and 12 after sachet treatment. Data (mean $\pm \mathrm{SE}, \mathrm{n}=18$ ) for each cultivar and ethylene treatment time followed by different letters are significantly different at $P=0.05$.

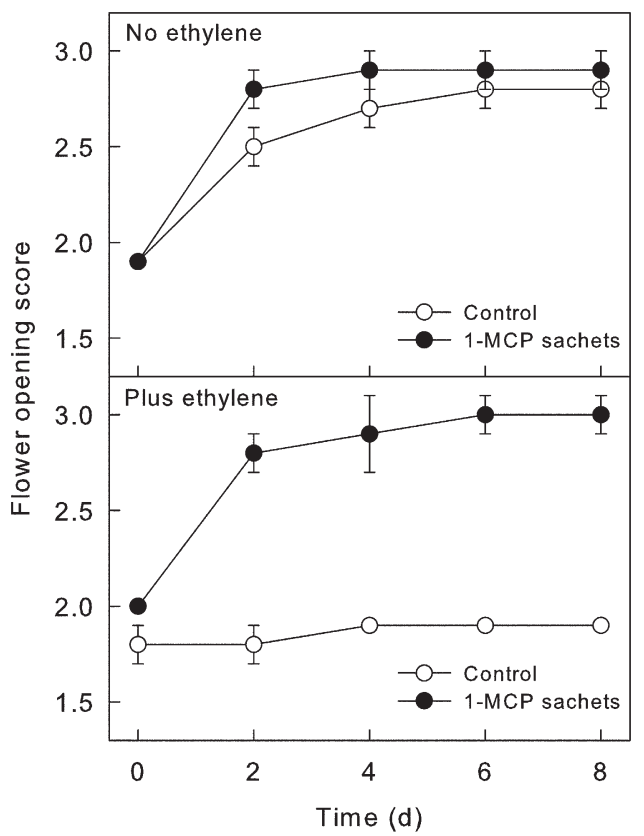

Fig. 6. Change in the opening of rose (Rosa $\times$ hybrida) 'Freedom' flowers during vase life at $21^{\circ} \mathrm{C}$. Flowers were hydrated in the commercial hydration solution for $16 \mathrm{~h}$ at $2{ }^{\circ} \mathrm{C}$. They were transported from the farm to the laboratory in $6 \mathrm{~d}$ in boxes containing zero (control) or two EthylBloc ${ }^{\mathrm{TM}}$ sachets that released 1-methylcyclopropene (1-MCP). Randomly sampled flowers were then immediately exposed to 0 or $1 \mu \mathrm{L} \cdot \mathrm{L}^{-1}$ ethylene for $24 \mathrm{~h}$ at $21^{\circ} \mathrm{C}$. Data represent the mean $\pm \mathrm{SE}(\mathrm{n}=18)$.

that it can provide cut flowers with longer-term (greater than $10 \mathrm{~d}$ ) protection (Macnish et al., 2000; Newman et al., 1998). This suggests that insufficient silver was present or available in flower tissues where new ethylene receptors are forming (Macnish et al., 2004b).

We also demonstrated that the release of 1-MCP from sachets containing EthylBloc ${ }^{\mathrm{TM}}$ into shipping boxes can protect sensitive rose flowers against ethylene during shipment (Figs. 3, 4, and 5). This treatment was at least as effective as 1-MCP fumigation before export (Fig. 3) and represents a simple alternative mode of application. However, the duration of protection provided by the 1-MCP sachets was transient and varied with genotype. Treatment efficacy was also dependent on temperature. For example, exposure to 1-MCP from sachets during shipment continued to afford 'Osiana' flowers with partial protection against ethylene for a further $6 \mathrm{~d}$ post-shipment when they were maintained at $3{ }^{\circ} \mathrm{C}$ (Figs. 5 and 6 ) but not at $21^{\circ} \mathrm{C}$ (Fig. 4). Our data are in agreement with those of Cameron and Reid (2001) that low temperature delays the recovery of ethylene sensitivity of 1-MCP-treated tissues, presumably by lowering rates of metabolic reactions associated with new ethylene receptor synthesis. Given that commercial shipment times and temperatures can vary, multiple or slowrelease 1-MCP treatments during shipping may improve protection of cut flowers against ethylene (Cameron and Reid, 2001; Macnish et al., 2004b).

The current study highlights particular Rosa $\times$ hybrida cultivars that require careful handling and treatments such as 1-MCP sachets to reduce ethylene-related quality loss. Our data represent the performance of cut flowers after commercial shipment, and we suggest this provides a meaningful test for evaluating new cultivars and postharvest treatments. The variation in the postharvest performance and ethylene sensitivity among current cut rose flower cultivars should be used for breeding and selection of genotypes with greater durability for commercial handling. Determination of the genetic basis for the variation among genotypes may provide opportunities to develop cultivars that are largely resistant to ethylene.

\section{Literature Cited}

Ahmadi, N., H. Mibus, and M. Serek. 2009. Characterization of ethylene-induced organ abscission in F1 breeding lines of miniature roses (Rosa hybrida L.). Postharvest Biol. Technol. 52:260-266.

Bleecker, A.B. and H. Kende. 2000. Ethylene: A gaseous signal molecule in plants. Annu. Rev. Cell Dev. Biol. 16:1-18.

Cairns, T., M. Young, J. Adams, and B. Edberg. 2000. Modern roses XI: The world encyclopedia of roses. Academic Press, San Diego, CA.

Cameron, A.C. and M.S. Reid. 2001. 1-MCP blocks ethylene-induced petal abscission of Pelargonium peltatum but the effect is transient. Postharvest Biol. Technol. 22:169-177.

Daly, J. and B. Kourelis. 2000. Synthesis methods, complexes and delivery methods for the safe and convenient storage, transport and application of compounds for inhibiting the ethylene response in plants. U.S. Patent 6017849.

Halevy, A.H. and S. Mayak. 1979. Senescence and postharvest physiology of cut flowersPart 1. Hort. Rev. (Amer. Soc. Hort. Sci.) 1: 204-236.

Kostansek, E.C. 2002. Delivery systems for cyclopropenes requiring less water. U.S. Patent 6426319. 
Kuiper, D., H.S. van Reenen, and S.A. Ribot. 1996. Characterisation of flower bud opening in roses; a comparison of Madelon and Sonia roses. Postharvest Biol. Technol. 9:75-86.

Macnish, A.J., D.E. Irving, D.C. Joyce, V. Vithanage, A.H. Wearing, and A.T. Lisle. 2004a. Variation in ethylene-induced postharvest flower abscission responses among Chamelaucium Desf. (Myrtaceae) genotypes. Scientia Hort. 102: 415-432.

Macnish, A.J., D.C. Joyce, D.E. Irving, and A.H. Wearing. 2004b. A simple sustained release device for the ethylene binding inhibitor 1methylcylcopropene. Postharvest Biol. Technol. 32:321-338.

Macnish, A.J., D.C. Joyce, P.J. Hofman, D.H. Simons, and M.S. Reid. 2000. 1-Methylcyclopropene treatment efficacy in preventing ethylene perception in banana fruit and grevillea and waxflower flowers. Aust. J. Exp. Agr. 40:471-481.

Muller, R., A.S. Andersen, and M. Serek. 1998. Differences in display life of miniature potted roses (Rosa hybrida L.). Scientia Hort. 76:5971.

Muller, R., E.C. Sisler, and M. Serek. 2000. Stress induced ethylene production, ethylene binding, and the response to the ethylene action inhibitor 1-MCP in miniature roses. Scientia Hort. 83:51-59.

Nell, T.A. 1992. Taking silver safely out of the longevity picture. GrowerTalks June:35-42.

Newman, J.P., L.L. Dodge, and M.S. Reid. 1998. Evaluation of ethylene inhibitors for postharvest treatment of Gypsophila paniculata L. HortTechnology 8:58-63.
Nowak, J. and R.M. Rudnicki. 1990. Postharvest handling and storage of cut flowers, florist greens and potted plants. Chapman and Hall, London, UK.

Onozaki, T., H. Ikeda, and T. Yamaguchi. 2001. Genetic improvement of vase life of carnation flowers by crossing and selection. Scientia Hort. 87:107-120.

Reid, M.S. and F.G. Celikel. 2008. Use of 1methylcyclopropene in ornamentals: Carnations as a model system for understanding mode of action. HortScience 43:95-98.

Reid, M.S. and G.L. Staby. 2008. A brief history of 1-methylcyclopropene. HortScience 43: 83-85.

Reid, M.S., R.Y. Evans, L. Dodge, and Y. Mor. 1989. Ethylene and silver thiosulfate influence opening of cut rose flowers. J. Amer. Soc. Hort. Sci. 114:436-440.

Serek, M. and M.S. Reid. 2000. Ethylene and postharvest performance of potted kalanchoe. Postharvest Biol. Technol. 18:43-48.

Serek, M., E.C. Sisler, and M.S. Reid. 1994. Novel gaseous ethylene binding inhibitor prevents ethylene effects in potted flowering plants. J. Amer. Soc. Hort. Sci. 119:1230-1233.

Serek, M., E.C. Sisler, and M.S. Reid. 1995. Effects of 1-MCP on the vase life and ethylene response of cut flowers. Plant Growth Regulat. 16:93-97.

Skog, L.J., T. Blom, B. Schaefer, B. Digweed, H. Fraser, and W. Brown. 2001. A survey of ethylene contamination in Ontario's floriculture industry and the evaluation of 1-methylcyclopropene and an ethylene absorber as potential solutions. Acta Hort. 543:55-62.
Sun, Q., T.L. Rost, M.S. Reid, and M.A. Matthews. 2007. Ethylene and not embolism is required for wound-induced tylose development in stems of grapevines. Plant Physiol. 145:1629-1636.

Tan, H., X. Liu, N. Ma, J. Xue, W. Lu, J. Bai, and J. Gao. 2006. Ethylene-influenced flower opening and expression of genes encoding Etrs, Ctrs, and Ein3s in two cut rose cultivars. Postharvest Biol. Technol. 40:97-105.

van Doorn, W.G. 2001. Categories of petal senescence and abscission: A re-evaluation. Ann. Bot. (Lond.) 87:447-456.

van Doorn, W.G., H. Harkema, and E. Otma. 1991. Is vascular blockage in stems of cut lilac flowers mediated by ethylene? Acta Hort. 298:177-181.

Woltering, E.J. and W.G. van Doorn. 1988. Role of ethylene in senescence of petals-Morphological and taxonomical relationships. J. Expt. Bot. 39:1605-1616.

Wu, M.J., W.G. van Doorn, and M.S. Reid. 1991a. Variation in the senescence of carnation ( $\mathrm{Di}$ anthus caryophyllus L.) cultivars. I. Comparison of flower life, respiration and ethylene biosynthesis. Scientia Hort. 48:99-107.

Wu, M.J., L. Zacarias, and M.S. Reid. $1991 \mathrm{~b}$. Variation in the senescence of carnation (Dianthus caryophyllus L.) cultivars. II. Comparison of sensitivity to exogenous ethylene and of ethylene binding. Scientia Hort. 48:109116.

Xue, J., F. Yang, and J. Gao. 2009. Isolation of $R h$ $T I P 1 ; 1$, an aquaporin gene and its expression in rose flowers in response to ethylene and water deficit. Postharvest Biol. Technol. 51: 407-413. 